\title{
Paradigm Shift of Beauty In Landscape Design: Strategies Towards 'Big Foot' Aesthetic
}

\author{
Lucia Indah Pramanti \\ Department of Architecture, Universitas Tarumanagara Jakarta \\ Email:luciap@ft.untar.ac.id
}

\begin{abstract}
Human perception about beauty always mirrors civilization, and is embodied in their built environment. In other words, what people sees as beautiful plays a crucial role towards how nature/landscape is developed. This paper intentions are to rethink on contemporary aesthetic value in landscape design, to evaluate current aesthetic paradigm, and to find landscape design strategies that can promote sustainable goals. Using qualitative method, this paper first shows historical review on how landscape form through many centuries in both western and eastern civilization. Later, it examines on how contemporary landscapes are built. In the discussion, it is found that -using Chinese foot binding tradition as a metaphor-our contemporary landscape is designed to be unusable, unhealthy, unproductive 'small feet'. Landscape is designed with beautification-merely for visual properties, not for human activity, destructing the natural properties of landscape, and too difficult to maintain. Human should be able to interact with the nature in landscape in order to create a behavioral changes towards the nature. As a conclusion, we need to shift our paradigm of beauty towards healthy 'big foot' aesthetic to be a direction on how to achieve the sustainable beauty. This 'big foot' aesthetic can be relevant not only in landscape design, but also in other fields related to the built environment.
\end{abstract}

Keywords: landscape design, sustainability, green design, aesthetic value

\section{INTRODUCTION}

Aesthetic value keeps changing throughout time mirroring the condition of human civilization. This phenomenon was explained by Alan Powers (2010) that the "story of our thinking about beauty could be seen as a single movement from certainty to doubt". What people see as a beauty today may be perceived as ugly after a period of time. This story of certainty and doubt for many centuries has led us to today, where 'green design' and 'sustainability' are the main concepts of development in wide range of fields in $21^{\text {st }}$ century (Boults and Sullivan, 2010). These concepts are trying to solve the problems that we are facing such as limited clean water, endangered living species and energy resources, climate changes, massive urbanization, and many other problems.

Many researchers argued that beauty or aesthetic factor in landscape design plays an important role towards sustainability (Meyer, 2008; Howett, 1987; Spirn, 1988). Beauty that provoked emotions will enable people to relate more to the nature and then changes their behaviour towards their environment. In other words, our perspective about aesthetic value contributes on how we behave and how we shape our space. Therefore, how modern society perceives beauty need to be examined and revisited. This research is aiming to find what are aesthetic values that can be pursued by modern designers to promote sustainability goals.

\section{WHAT IS CONSIDERED AS AESTHETIC? A HISTORY OVERVIEW}

"Beauty: that quality or combination of qualities which affords keen pleasure to other senses (e.g. hearing) or which charms the intellectual or moral faculties, through inherent grace, or fitness to a desired end." (Oxford English Dictionary, 2002)

As briefly mentioned earlier, what people see as beautiful mirrors the civilization. Firstly, we need to explore how landscape changes through time. The following table summarizes how beauty values has changed in the western civilization from middle age up to date. 
Table 1. Landscape through western civilization (Source: Boults and Sullivan, 2010; Powers, 2010)

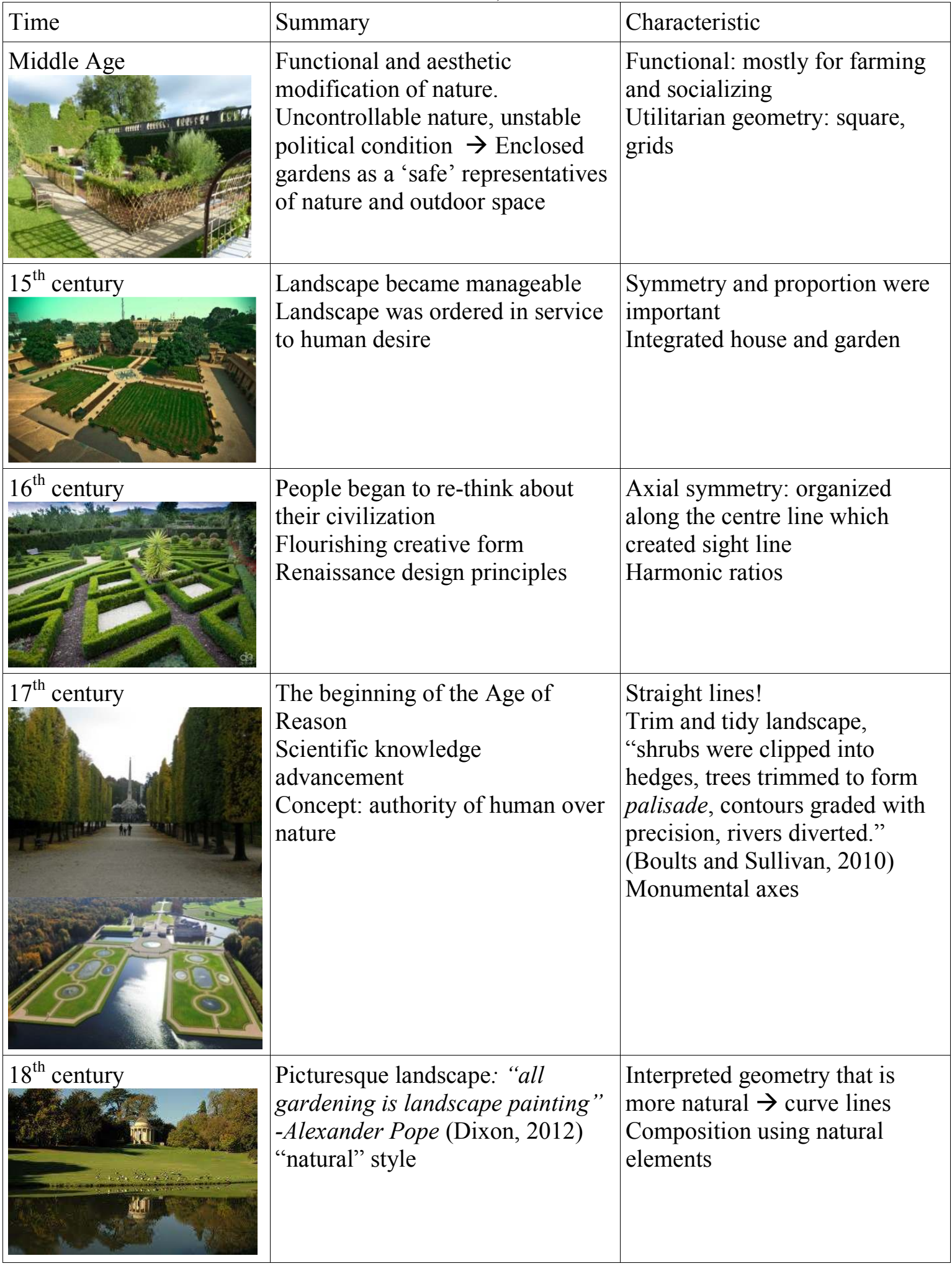




\begin{tabular}{|l|l|l|}
\hline $19^{\text {th }}$ century & $\begin{array}{l}\text { Industrial revolution } \rightarrow \text { eroded } \\
\text { agriculture land, urbanization } \\
\text { Starting point of city } \\
\text { beautification movement } \\
\text { People understood the political, } \\
\text { ocial, economic value of } \\
\text { landscape. }\end{array}$ & $\begin{array}{l}\text { Accessibility: social factor } \\
\text { awareness } \\
\text { Identity } \\
\text { Urban, public and romantic }\end{array}$ \\
\hline $20^{\text {th }}$ century & $\begin{array}{l}\text { Originality, open to new ideas } \\
\text { Moral component in the design } \\
\text { Very diverse } \rightarrow \text { no style or } \\
\text { approach can represent this } \\
\text { century }\end{array}$ & $\begin{array}{l}\text { Utility / functional } \\
\text { Expressing the true nature of } \\
\text { materials }\end{array}$ \\
\hline $21^{\text {st }}$ century & $\begin{array}{l}\text { High mobility, network, instant } \\
\text { "green" trend } \\
\text { Combining art and } \\
\text { science/technology to create } \\
\text { beautiful yet responsible design }\end{array}$ & $\begin{array}{l}\text { Ecological } \\
\text { Reduce, reuse, recycle } \\
\text { Sustainable }\end{array}$ \\
\hline
\end{tabular}

This table above reflects that for many centuries, human tried to conquer and 'shape' the nature according to their perception of beauty. Human sees unpredictability and ruggedness of nature's wild spaces as an unwelcomed discomfort (Varley and Medway, 2011). We 'paint' using nature and define landscape beauty into a specific form or associated in certain emotional responses.

In the last few decades, many landscape designers are discussing about experiential and ecological importance in landscape design. This concept had been sounded in 1987 by Howett where he explained that beauty will be shown by landscape design that responses to the whole system including topography, climate, hydrology, flora and fauna, and also human life. The experience in that whole system is not simply an act of pleasure, but possibly, one of transformation.

\section{ASIA CONTEXT: CHINESE LANDSCAPE}

Asia has a landscape has a different landscape characteristic mirroring its culture and societies. In this paper, China is chosen as an illustration for its long history of civilization with sufficient recorded data.

\section{Chinese Traditional Landscape}

In China's eraly civilization, their landscape design started as rural agriculture. This landscape is not 'designed' with visual beauty as its goal but with utility in mind, but developed using skills passed through generation and derived from years of adaptation. 


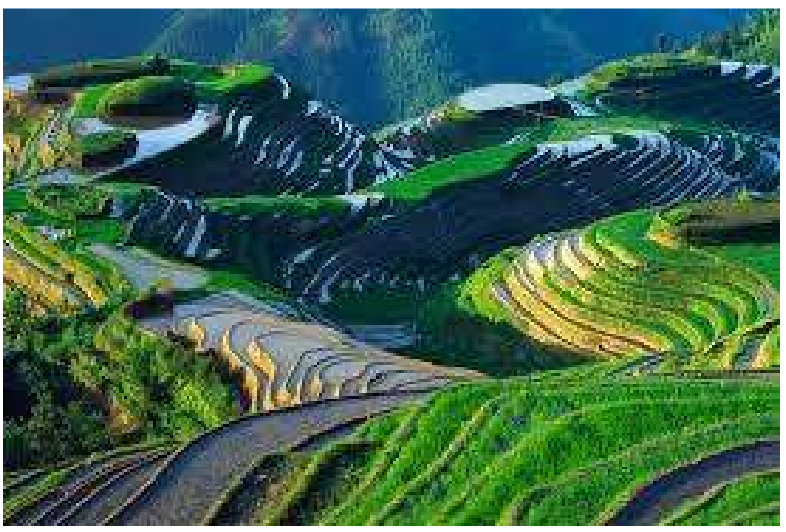

Figure 1- Chinese traditional agricultural landscape

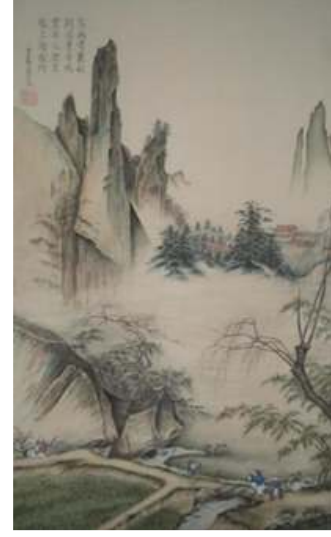

Figure 2- Chinese landscape painting showing the 'land of peach blossom'

This form of landscape is then considered as beautiful by Chinese people who later depicted the landscape in a Chinese tale named "Land of peach blossoms". This tale describes the journey of a farmer that walks from the narrow, 'mysterious' landscape, and a sudden view of a vast beautiful landscape where people live in harmony. (Bokenkamp, 1986). It pictures a utopian ideal living place and its beauty: living in harmony with the nature.

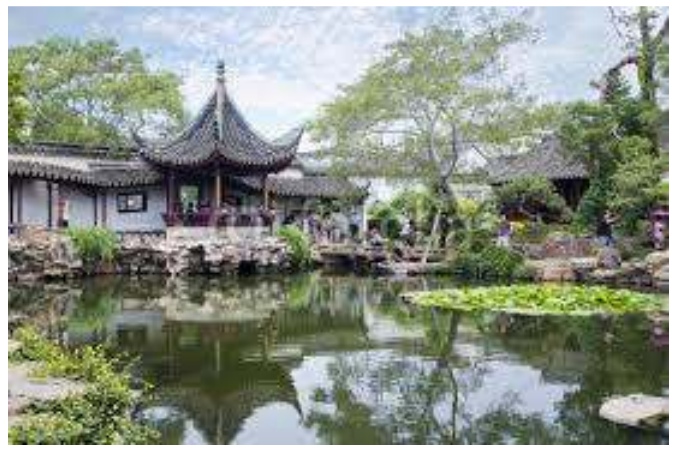

Figure 3- Garden as a miniature of nature. The rocks represent mountain, the pond represent the lake/sea

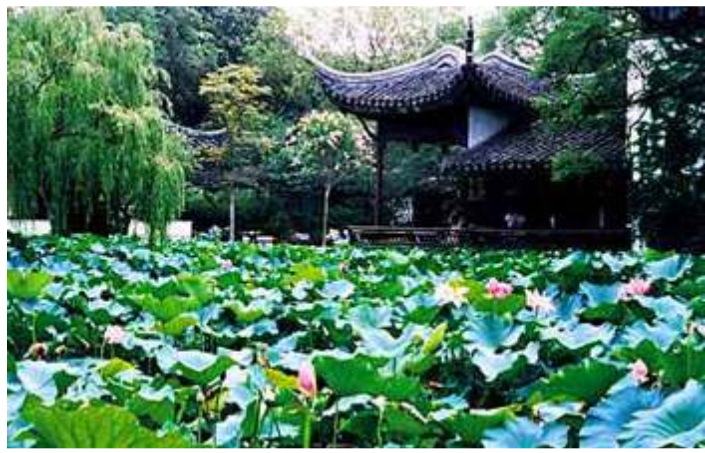

Figure 4- Lotus as symbol of love in Chinese garden

As the civilization develops, Chinese started to build designed gardens. This concept is to form human idealized miniature landscape. It was a showcase to display the cultivation and aesthetic taste of the owner (Department of Asian Art, 2004). Landscape in Chinese gardens delivers beauty by symbols and meanings rather than by form, geometric shape and symmetry. Each plant is chosen more for their symbolic attributes rather than their sensual qualities (Boults and Sullivan, 2010). For example, pine trees for longevity, plum for endurance, bamboo for resilience, orchids for grace, and chrysanthemum for nobility. These symbols are intended to inspire people by the relationship between nature, human and their work. These main purpose is creating a space where people can relate and contemplate about nature.

\section{Chinese beautification movement}

"'Beauty' is not the same with 'beautification' that the latter is limited at formal and visual aspects." (Meyer, 2008). 
Statement above reflects on how beautification is considered as a superficial effort to make something beautiful. It is often done as a work of 'ornamentation' whereas beauty has a deeper understanding than merely visual and formal aspects. We can easily find beautification in our everyday environments. Along with the growing economic condition, many landscape designs developing countries in Asia are copying those in the western as a 'developed modern world' precedent. Contemporary landscape, architecture and urban design simply reflect the aspirations of ordinary people to become sophisticates (Saunders, 2013). China is one of the countries whose landscape designs are following those in the western, some of them are exact copies (see Fig. 5). Others are trying to copy previous traditional garden landscape. However, the aesthetic approach they make only based on visual aspect. For example, While Chinese traditional gardens use big rocks to represent mountains, the contemporary garden are using artificial rocks from concrete.

These beautification movements in Asia are following the same movements in America and Europe despite of many researchers had criticized that it is no longer suitable for current development. (Bluestone, 1988; Jacobs, 2016; Stelter, 2000; Ward, 2000)

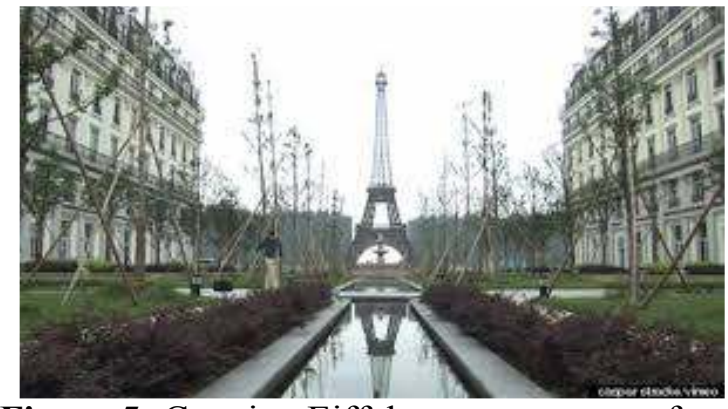

Figure 5- Copying Eiffel tower as a part of city beautification movement. The landscape itself is rarely used

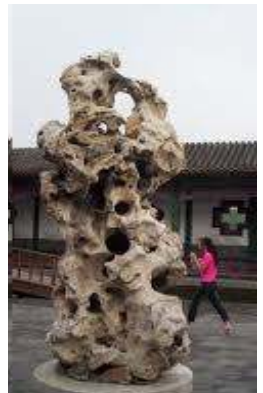

Figure 6- Artificial rock for garden ornament

\section{DISCUSSION: 'SMALL FEET' VS 'BIG FEET' AESTHETIC}

Kongjian Yu created an analogy of landscape design with Chinese binding feet tradition which had happened for hundreds of years until it collapsed on 1911 (Saunders, 2013). At that time, Chinese girls bound their feet to show high-status so they could marry elites. Normal feet or 'Big feet' was associated with peasant, provincial, people worth low social status. Interesting that at that time, when compared to strong and healthy feet, the crippled and abused feet was seen as the beautiful ones. However, we can also learn from the phenomenon that the unnatural form of beauty cannot perform well. Nowadays, most people will consider the bound feet as grotesque rather than beautiful.

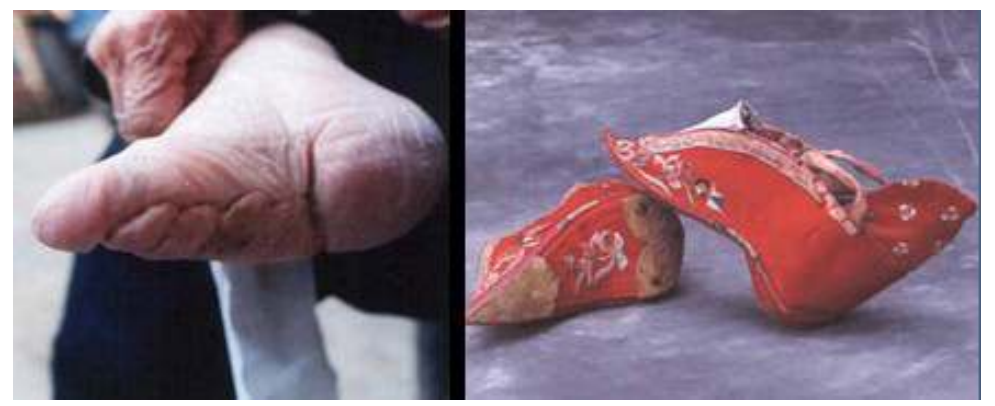

Figure 7- Chinese bound feet: once beautiful, now grotesque 


\section{Critique on beautification - 'small feet' aesthetic}

We often find many examples of 'small feet' landscape beauty where beauty is seen by the form, not by the function. Landscape becomes some form of sculptural or painting with shallow meaning of beauty - without having any function or purpose.

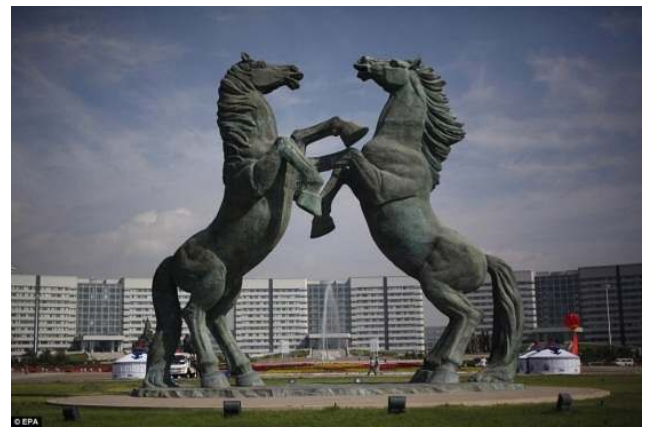

Figure 8- The 'so-called' beautiful landscape without users.

Designers often play the role of 'elites' or 'Gods' with their subjective opinions on beauty instead of focusing on nature and people. Value of one place is determined by the material it uses and to protect what so called beautiful garden, they put signage that forbid people to step on the grass and enjoy the landscape. The result is limited comfort and activities thus yielding only limited or no experience with the landscape.

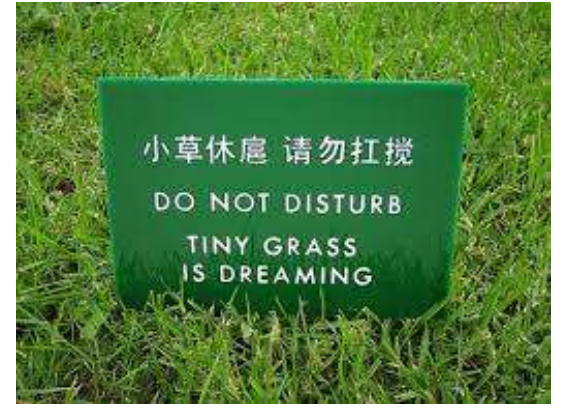

Figure 9- do not step on the grass signage limiting interaction

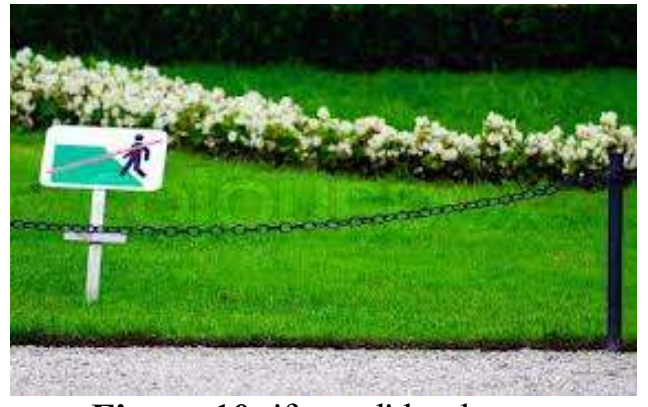

Figure 10- 'fenced' landscape

People nowadays become more and more detached with their landscape and natural realm. Their surrounding landscape is not welcoming for engagement making them see it as an object. Therefore the behaviour of destroying nature becomes understandable as they do not feel that the nature is a part of their life.

Sophisticated landscape design with without people, gardens with grass that is protected from people, imported plants that require a lot of resource to maintain - these examples of 'small feet' aesthetic are not a sustainable development. We might have seen it as a beauty but now, however, we need to shift our paradigm of beauty: from unnatural, useless, 'small feet' to healthy and productive 'big feet'.

\section{What is 'big foot' aesthetic'?}

Human developed utilitarian/traditional rural landscape that falls into the 'big foot' aesthetic category a long time ago. For thousands of years, farmers live in landscape with skills that has been passed through generations. The built landscapes are acquired from countless trials and 
errors, adaptation through many changes and natural disaster. This rural landscape is considered as beauty not just for its appearance, but also for its performance. This 'big foot' aesthetic is the sustainable aesthetic.

Firstly, beautiful landscape is productive, ecologically or agricultural: produce food, clean water, or provide habitat, etc. In short, landscape should have a certain purpose. Elizabeth Meyer (2008) also had similar statement which she called it 'performing landscape'. Landscape that has function is seen by the users as more than just pretty or beautiful, it is also meaningful.

Natural properties have to be seen as an opportunity to create that purpose. 'Messy' nature should be regarded as beautiful because there lays the great potential. For example, artificially channelled river using concrete loses the nooks and crannies where natural ecosystem lives. This ecosystem that once naturally cleaned the water is now missing. Although the artificial landscape is considered as tidy and manageable by some people, but tidiness can make the river to lose its natural properties.

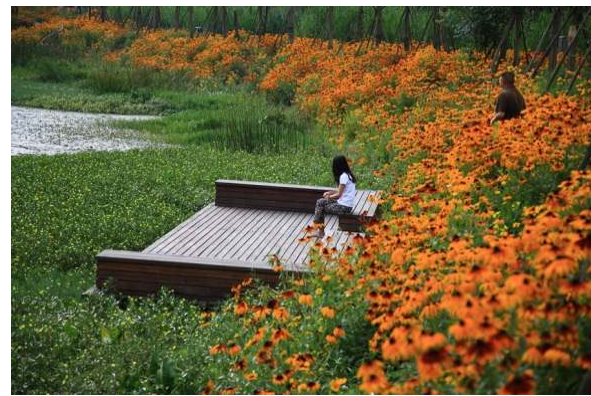

Figure 11- The beauty of 'messy' nature

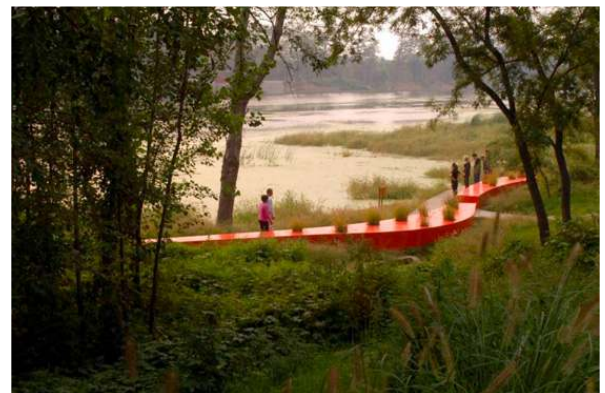

Figure 12- Red stripe landscape elements: framing nature and providing space for activity

This does not mean that we should preserve landscape as wild nature, because wilderness can be easily neglected. It also does not mean the other elements of design should be as 'messy' as the nature element consequently becomes difficult to contain activities. Design should 'frame' the nature instead of 'paint' using nature elements. This frame allows human activity to further enhance the purpose of the landscape.

With the aim of contain people's activities, landscape must be usable, not only enabling people to enjoy being in the nature but also inserting beauty in people's everyday life and activity (usable over picturesque). This 'vernacular' aesthetic or 'people' aesthetic will reflect the culture of the place. That is why gardens should not be gated but on the contrary, should encourage people's activity. Landscape should be accessible for people to immerse themselves in the nature, and let people experience and learn something from it.

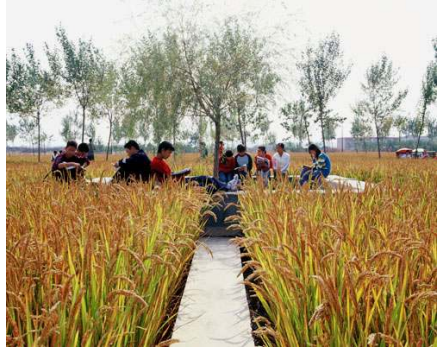

Figure 13- Public space in the rice field garden. 
Landscape should also be dynamic, resilient, and welcoming changes. Planting local plants are encouraged since exotic (foreign) plants will need artificial conditioning and continuous maintenance. Weeds are welcomed and they actually contribute to the whole landscape composition. Then difficult extensive trimmings are not needed, maintenance work is minimum and affordable. The local plants, water bodies, animal creatures also have certain cultural value because it is specific to one place - this is where landscape can also be a socio-cultural identity.

\section{CONCLUSION}

There is a serious necessity to change modern perspective on aesthetic. We should not fight against the unpredictable force of nature. We should move our paradigm - what we sees as beauty: from grotesque 'small foot' to healthy and productive 'big foot'. Landscape designers should consider nature and its properties as an opportunity rather than threat and frame the nature as a form of beauty that can enrich users' experience and at the same time, improve the ecology. Experience that will be acquired from the journey in the landscape will be embedded in people's memory and can improve their view about landscape beauty and sustainability.

The range of 'big foot' aesthetic in landscape design can range from combining landscape with existing structure, inserting the landscape into architecture, and also in large scale as national landscape planning. This paradigm is also extensively relevant and applicable to other fields that affect the built environment.

\section{REFERENCES}

Bluestone, Daniel M. "Detroit's city beautiful and the problem of commerce." Journal of the Society of Architectural Historians 47.3 (1988): 245-262.

Bokenkamp, Stephen R. "The Peach Flower Font and the Grotto Passage." Journal of the American Oriental Society 106.1 (1986): 65-77.

Boults, Elizabeth, and Chip Sullivan. Illustrated history of landscape design. John Wiley \& Sons, 2010.

Department of Asian Art. Chinese Gardens and Collectors' Rocks. In Heilbrunn Timeline of Art History. New York: The Metropolitan Museum of Art, 2000-. http://www.metmuseum.org/toah/hd/cgrk/hd_cgrk.htm (Oct 2004)

Dictionary, Oxford English. "Oxford English Dictionary." The Library (2002).

Dixon Hunt, John. "Picturesque \& the America of William Birch 'The singular excellence of Britain for picture scenes'." Studies in the History of Gardens \& Designed Landscapes 32.1 (2012): 3-14.

Howett, Catherine. "Systems, signs, sensibilities: sources for a new landscape aesthetic." Landscape Journal 6.1 (1987): 1-12.

Jacobs, Jane. The death and life of great American cities. Vintage, 2016.

Meyer, Elizabeth K. "Sustaining beauty: The performance of appearance (Reprinted from'Journal of Landscape Architecture', Spring 2008)." Landscape architecture 98.10 (2008): 92.

Powers, Alan. Robin Hood Gardens Re-visions. The Twentieth Century Society/Paul Holberton Publishing, 2010.

Saunders, William S., ed. Designed ecologies: The landscape architecture of Kongjian Yu. Walter de Gruyter, 2013.

Spirn, Anne Whiston. "The poetics of city and nature: Towards a new aesthetic for urban design." Landscape Journal 7.2 (1988): 108-126.

Stelter, Gilbert. "Rethinking the significance of the city beautiful idea." Urban Planning in a Changing World: The Twentieth Century Experience (2000): 98-117. 
Varley, Peter, and Dominic Medway. "Ecosophy and tourism: Rethinking a mountain resort." Tourism Management 32.4 (2011): 902-911.

Ward, Andrew. Assessment of Garden City Planning Principles in the ACT. Department of Territory and Municipal Services, 2000. 